\title{
Summer mortality of hatchery-produced Pacific oyster spat (Crassostrea gigas). II. Response to selection for survival and its influence on growth and yield
}

\author{
Lionel Dégremont ${ }^{\mathrm{a},{ }^{*}}$, Edouard Bédier $^{\mathrm{b}}$ and Pierre Boudry ${ }^{\mathrm{c}}$
}

\footnotetext{
a IFREMER, Laboratoire de Génétique et Pathologie, F-17390 La Tremblade, France

b IFREMER, Laboratoire Environnement Ressources Morbihan Pays de Loire, Ifremer, F-56470 La Trinité, France

IFREMER, UMR M100 Physiologie et Ecophysiologie des Mollusques Marins, Plouzané, France
}

*: Corresponding author : Lionel Dégremont ? Tel.: +33 5467626 30; fax: +33 5467626 11, email address : lionel.degremont@ifremer.fr

\begin{abstract}
:
Response to divergent selection for "high" and "low" survival during the summer period, from July to October, was investigated in juvenile (six-month-old) Pacific oysters, Crassostrea gigas, by producing two sets of progenies in 2002 (Generation 2) and three sets of progenies in 2003 (Generation 3). A strict between-family approach was used and resistance of these selected progenies to summer mortality was assessed in three sites along French coasts, to determine their response to selection and estimate realized heritability of the trait. A significant difference in survival was observed between the "high" and "low" selected groups at all sites for all sets of progenies, indicating a significant genetic component. High realized heritabilities for survival obtained from Generation 2 oysters, ranging from $0.61 \pm 0.08$ to $0.98 \pm 0.15$, were in line with previous results from the first generation. Finally, Generation 3 realized heritability, ranging from $0.55 \pm 0.18$ to $0.81 \pm 0.13$, supported results from Generation 2. Our results demonstrate that selective breeding to improve survival during the first summer can be successfully implemented and should lead to rapid gains. Overall, selection on survival did not have any impact on growth, although it did have one on yield.
\end{abstract}

Keywords: Crassostrea gigas; heritability; juveniles; summer mortality; survival; growth 


\section{Introduction}

Selective breeding programs for oysters have focused primarily on improving growth rate, disease resistance, survival, shell shape and color (for review, see Sheridan, 1997). Many studies on disease resistance and survival have revealed significant genetic variation between populations (e.g. Soletchnik et al., 2002), providing evidence for a genetic basis to these traits. For example, Crassostrea virginica production in the Malpeque Bay, Canada, started to decrease from 1915 due to high mortality rates (Needler and Logie, 1947). However, natural reconstitution of populations was recorded in the bay in subsequent years, suggesting that natural selection for more resistant oysters was taking place despite the prevalence of infectious agents throughout these resistant stocks. In Chesapeake and Delaware Bays, on the East Coast of the USA, mortality events have also been reported for the eastern oyster $C$. virginica due to two protozoa: Haplosporidium nelsoni (MSX) and Perkinsus marinus (Dermo) (Haskin et al., 1966; Burreson, 1991). Development of disease-resistant oysters through selective breeding programs, in which surviving oysters from disease-endemic areas are selected and bred over successive generations, have decreased disease-related mortality, especially for MSX (Haskin and Ford, 1979, Ford and Haskin, 1987, Chintala and Fisher, 1991; Calvo et al., 2003). Similar results were observed for Ostrea edulis exposed to Bonamia ostreae, with higher survival and lower disease prevalence in the selected group compared with control animals (Elston et al., 1987; Baud et al., 1997; Naciri-Graven et al., 1998, Culloty et al., 2004). In Juvenile Oyster Disease (JOD) caused by Roseovarius crassostreae, C. virginica mortality rates are lower if individuals are $>25 \mathrm{~mm}$ when first exposed to the disease (Davis and Barber, 1994; Barber et al., 1996, Boettcher et al., 2005). Selective breeding for increased growth could therefore be used to improve oyster survival indirectly, so that oysters reached a 'refuge' size, at which they were less susceptible to JOD, at an earlier age (Barber et al., 1998; Davis and Barber, 1999). Alternatively, improving JOD resistance by selective breeding on the resistance itself is also effective due to its high heritability (Farley et al., 1997, 1998).

However, when the cause of mortality is more complex, as in the case of summer mortality in the Pacific oyster $C$. gigas, selecting resistant stocks by challenge-based methods is more problematic. In fact, summer mortality arises from a complex interaction between the oyster, its environment and the presence of opportunistic pathogens (Samain and McCombie, 2008). Basically, throughout the world, reports of summer mortality are most common when seawater temperatures are high (Koganezawa, 1975, Goulletquer et al., 1998, Cheney et al., 2000) and nutrients are abundant (Lipovsky and Chew, 1972, Glude, 1975). Thus, a selective breeding program to reduce summer mortality on the West Coast of the USA was based on heat challenge (Beattie et al., 1980). This breeding program, based on thermally challenging the broodstock, resulted in significant increases in survival among the resulting progeny. Hershberger et al. (1984) reported that average mortality rates of third generation selected families of this program ranged from $13 \%$ to $23 \%$ compared with $62 \%$ for the control group.

All these previous experiments describe genetic enhancements which have been broadly applied in aquaculture (Newkirk, 1980; Fjalestad et al., 1993; Hulata, 2001). However, optimization of genetic improvement through selection requires the estimation of genetic parameters for survival and/or disease resistance. Genetic parameters have recently been reported for survival during the summer period in Crassostrea gigas in France (Dégremont et al., 2007) and on the West coast of the USA (Evans and Langdon, 2006). However, little data is available concerning realized heritability for survival in oysters, or indeed marine bivalves in general. According to results obtained from a first generation (Generation 1) in 2001 in the MOREST program (Samain and McCombie, 2008), significant differences in field survival were observed between full- and half-sib families of C. gigas (Dégremont et al., 2005, 2007). Families showed variable levels of mortality with consistent inter-family differences at all tested 
sites, providing very strong evidence to support a significant genetic basis for survival. High heritability of survival rate found in Generation 1 indicates that selective breeding programs could effectively improve the survival of juvenile oysters (Dégremont et al., 2007). It was the purpose of this study to look at the effects of such selection on this living material. First, in order to assess whether improved survival during the summer period could be achieved, and to confirm the trends shown by the Generation 1 results, divergent selection was applied to estimate the response to selection and the realized heritability for survival in juvenile C. gigas. Second, the effects of this selection on growth and yield were investigated.

\section{Materials and methods}

Two generations were produced for the present study, descended from the existing Generation 1, these will be referred to as Generation 2 and Generation 3. Generation 2 was produced from two sets of crosses between parental oysters from Generation 1. Generation 3 was then produced one year later using three sets of crosses between parental oysters from Generation 2 (as detailed below). Selection was done between Generation 1 and Generation 2, while Generation 3 was simply propagations of the batches produced in Generation 2 in the absence of additional selection. All progenies were produced following a divergent selection mating design as this method enables heritability estimates to be made from parent-offspring regression, which is a more accurate means than half-sib analysis when the heritability exceeds 0.25 (Robertson, 1959). Indeed, the selection of extreme phenotypes (here low and high survival) in Generation 1 increases the variance of survival (Hill, 1972a), allowing more information to be gathered with this regression (Falconer, 1981) and consequently improving the estimation of heritability by a reduction of its standard deviation (Hill and Thompson, 1977). Finally, differential selection allows the environmental effects common to all individuals of the two selected lines to be eliminated and thus allows more precise estimates of heritability to be obtained than with separate (one-way) selection, since the sum of squares of the selection differential is increased (Hill, 1971, 1972a).

\subsection{Generation 2}

Selection of families with "high" and "low" survival: On the basis of mean summer survival of Generation 1 at the three sites in 2001 (Dégremont et al., 2007), three good surviving (hereafter "high") and three bad surviving (hereafter "low") half-sib families (HSF), were selected to produce Generation 2. Each of these Generation 1 HSF was made up of 2 full-sib families (FSF) as described in Dégremont et al. (2007), which gives more details about Generation 1. Thus, HSF 2, 9 and 15 were chosen as "high" surviving families, and HSF 4, 7, and 14 were selected as "low" surviving families (Fig. 1 and Table 1).

Broodstock conditioning: The 6 HSF (12 FSF) selected from Generation 1 to serve as genitors had been produced in February, March and April 2001 in the Ifremer hatchery in La Tremblade (Charente Maritime, France) as described by Dégremont et al. (2005). Five hundred oysters per Generation 1 family were retained at the nursery in Bouin (Vendée, France) until the last week of September 2001. These oysters were thus not deployed in the field during the summer period for mortality assessment, but kept back in "safe" conditions (low mortality risk), while other individuals from the same families were tested in the field sites (as described in Dégremont et al., 2005) with all the other Generation 1 families. These future broodstock animals were then transferred to a pond in the Marennes-Oléron Bay until January 2002. Two groups of 60 oysters were chosen at random from each FSF and transferred to the conditioning 
room at the Ifremer hatchery in La Tremblade in January for the first group and in February for the second. The first group of broodstock was used to make crosses between FSF to produce the G2. The second group of broodstock was crossed within FSF to produce the G2c (Fig. 1 and Table 1). No groups of animals used as broodstock had experienced any previous summer mortality, with the exception of an FSF named F7-26 that had suffered $\sim 25 \%$ mortality during the nursery period in Bouin.

Crosses: To control the mating, gametes were collected by dissecting the gonad of each parent. The G2 and G2c were produced on March $18^{\text {th }}$ and April $29^{\text {th }} 2002$, respectively. Crosses between (or within) the "high" FSF produced 12 batches for the "high" selected line and crosses between (or within) the "low" FSF produced 12 batches for the "low" selected line (Table 1). To ensure that each selected FSF was well represented, a mean of 26 males and 27 females per FSF were used in each cross to produce the G2. The G2c was produced with a mean of 28 males and 30 females per FSF in each cross. Thus, as the G2 used two FSF to produce each progeny batch, 106 parents were used for this cross, while each progeny batch of G2c only involved one FSF and therefore only 58 parents (Table 1). For the G2, each progeny batch was derived from two reciprocal mass crosses. For example, females of FSF F9-35 were crossed with F2-5 males, and F2-5 females were crossed with F9-35 males. The offspring resulting from this reciprocal cross were pooled 30 minutes after fertilization to produce batch $A$ (Table 1 ). This method removed possible maternal or paternal non-genetic effects within the batch.

Control batches were produced for G2 and G2c using Generation 1 control groups that had been produced in 2001 (using 72 females and 18 males as parents). Four of these non-selected control batches were produced for $\mathrm{G} 2$ (named $\mathrm{Q}, \mathrm{T}, \mathrm{U}$ and $\mathrm{X}$ ) and three for G2c (named T2, X2 and U2). Each control was made by mixing gametes from 54 females and 60 males.

In summary, for G2, 12 batches were produced for the "high" selected line, 12 batches for the "low" selected line and four non-selected controls; for G2c, 12 batches were produced for the "high" selected line, 12 batches for the "low" selected line and three non-selected controls (Table 1).

\subsection{Generation 3}

Selection of parental batches and broodstock conditioning: Generation 2 batches were used to produce the G3 in 2003 (Fig. 1). As for the Generation 1 broodstock, 500 oysters per batch of Generation 2 were kept at the nursery during the summer period in order to protect them from any mortality. These oysters were transferred to Marennes-Oléron Bay in October 2002. Two months before spawning, 60 oysters per batch were transferred to the conditioning room at the Ifremer hatchery in La Tremblade.

Crosses: Three sets of crosses were performed in the G3. One non-selected control and two selected lines were produced each time, composed of 11 or 12 batches each (Table 2). The first set, G3 was produced on February $17^{\text {th }}$ using G2c oysters as parents (Table 2). The two other sets, G3c ${ }^{2}$ and G3c, were produced from the G2c and G2, respectively, on March $24^{\text {th }}$ and April $28^{\text {th }} 2003$ (Table 2).

When two different batches served as parents, reciprocal crosses were used as for the crosses used to produce the $\mathrm{G} 2$. The Generation 3 crosses were made with, on average, 46, 12 and 12 males and 46, 13 and 12 females as parents for the $G 3, G 3 c^{2}$ and $G 3 c$ respectively. The nonselected Generation 3 controls were bred from parents collected from the Marennes-Oléron Bay oyster population, using in average 11, 9 and 10 males and 17, 8 and 8 females as parents for the $\mathrm{G} 3, \mathrm{G}^{2} \mathrm{c}^{2}$ and $\mathrm{G} 3 \mathrm{c}$ respectively. 


\subsection{Larval and spat culture}

Protocols used for the larval to nursery stages are described in Dégremont et al. $(2005,2007)$. Briefly, larval rearing, settlement and a part of the nursery phase were performed at the Ifremer hatchery in La Tremblade. When spat reached $2 \mathrm{~mm}$ in size, they were transferred to the nursery in Bouin where they were reared until their deployment in the field

\subsection{Field experiment and data collection}

Spat of the $G 2$ were transferred to the field on July $11^{\text {th }} 2002$ at the same three sites along the French coast as those used to test Generation 1: Ronce in the Marennes-Oléron Bay ( $1^{\circ} 10^{\prime} \mathrm{W}$, $\left.45^{\circ} 48^{\prime} \mathrm{N}\right)$, Rivière d'Auray in Brittany $\left(2^{\circ} 57^{\prime} \mathrm{W}, 47^{\circ} 36^{\prime} \mathrm{N}\right)$, and Baie des Veys in Normandy $\left(1^{\circ} 06^{\prime} \mathrm{W}, 49^{\circ} 23^{\prime} \mathrm{N}\right)$. Due to the limited number of individuals in some batches, batch $\mathrm{F}$ of $\mathrm{G} 2$ was not tested in Baie des Veys and batches B, E, G, O and V were only tested in Ronce. Oysters were cultured in plastic mesh bags ( $7 \mathrm{~mm}$ mesh) fixed on racks, according to local practice. Each batch was represented by three bags of 150 oysters at each site. All batches were sampled for survival, growth and yield assessments on October $8^{\text {th }} 2002$. Additionally, six bags of 150 oysters for batches that produced a high number of spat were also deployed in order to verify whether handling stress could be responsible for mortality. These batches were sampled 15 and 42 days after deployment (three bags per sampling date).

For the G2c, spat were only deployed in Ronce where they were transferred on August $8^{\text {th }} 2002$. All batches were represented by three bags of 150 oysters. Survival, growth and yield were assessed on October $8^{\text {th }} 2002$.

For G3 testing, three bags of 150 spat per batch of the G3 were deployed in Rivière d'Auray on July $1^{\text {st }} 2003$. The same approach was taken with the oysters of the $G 3 c^{2}$ on July $16^{\text {th }}$ and for the oysters of the G3c on July $31^{\text {st }}$, only these were deployed in Ronce. At the end of the summer period on October $8^{\text {th }} 2003$, all bags were sampled for all sets to determine the survival, growth and yield.

Before deployment in the field, 200 oysters from each batch were individually weighed, and the total weight of the 150 oysters transferred into each bag was recorded. At each sampling date, dead and live oysters were counted for survival assessment and all live oysters were weighed to determine the yield (see section 2.5 for calculation). For growth, 30 oysters in each batch were individually weighed except when number could not be reached due to high mortality.

\subsection{Data analysis}

Statistical analyses are only presented for data collected on the last sampling date (i.e. October $8^{\text {th }} 2002$ for Generation 2 and October $8^{\text {th }} 2003$ for Generation 3).

Mortality analyses: Mortality was analyzed by a logistic regression for binomial data using SAS ${ }^{\circledR}$ software. For the G2, where lines were tested in the three sites, only batches present at all three sites were included in the statistical analyses, which used the following model:

Logit $\left(Y_{i j k l}\right)=\mu+$ line $_{i}+$ site $_{j}+$ batch $_{k(i)}+$ line $_{i} \times$ site $_{j}+$ site $_{j} \times$ batch $_{k(i)}+E_{i j k l}$

Where $\mathrm{Y}_{\mathrm{ijkl}}$ is mortality of the $I$ spat of the $k$ batch within the $i$ line in the $j$ site; $\mu=$ overall mean ; line $_{i}=$ line effect $\left(i=\right.$ non-selected, high- and low-selected); site ${ }_{j}=$ site effect $(j=$ Ronce, Rivière d'Auray, Baie des Veys); batch $_{k(i)}=$ batch effect $(k=1$ to 20$)$ within line; line ${ }_{i} \times$ site $_{j}=$ line-site interaction effect; site $e_{j}$ batch $_{k(i)}=$ site-batch interaction effect within group; and $E_{i j k l}=$ observation error.

Within site for all sets, the following model was used: 
Logit $\left(\mathrm{Y}_{i k l}\right)=\mu+$ line $_{i}+\operatorname{batch}_{k(i)}+\mathrm{E}_{i k l}$

Site, line and their interaction were considered as fixed effects while all other effects were random. Multiple comparison tests were conducted using the least squares means statement (SAS Institute Inc., 1995).

Growth: Individual weights were log transformed prior to statistical analysis. Growth was analyzed with the two models described above using an ANCOVA that incorporated length of time in the field as the continuous variable (SAS Institute Inc., 1989; see Taris et al., 2006 for more details). Multiple comparison tests used the Tukey method.

Daily yield: The daily yield $\left(\mathrm{Yd}, \% \cdot \mathrm{d}^{-1}\right)$ was defined as follows:

$\mathrm{Yd}=100^{*}$ (Wts-Wti) / (Wti*dps)

where $\mathrm{Wts}=$ total weight of live spat at the final sampling; $\mathrm{Wti}=$ initial total weight of live spat at the Bouin nursery, and dps = number of days in the field.

Analyses of variances were done using the same models as described for mortality analyses and multiple comparison tests made using the Tukey method.

Estimation of realized heritability: Realized heritabilities were estimated for each set of crosses in each site and also among sites for the G2, as the batches of this set were deployed in all three sites. The selection differential was calculated as the difference between the mean survival of the selected parents and the mean of the parental population before selection. Response to selection was calculated as the difference between the mean survival of the selected batch and the mean of their respective control to take into account bias related to the variation of environmental condition between years. The regression of response on selection differential was used to obtain estimates of realized heritability (Falconer and Mackay, 1996). As the selected lines originated from the same base population, the regression was constrained to pass through the origin (Hill, 1972b; Baker et al., 1991; Parnell et al., 1997).

\section{Results}

\subsection{Second generation - G2: between-HSF parentage}

Mortality: At the first sampling date, i.e. 15 days after deployment, mortality was low for all lines at all sites, ranging from 1.4 to $3.9 \%$. At the second sampling, 42 days after deployment, mortality was still low in Ronce (6.1\%) and Baie des Veys (3.5\%), whereas mortality was 19.6 $\%$ in Rivière d'Auray.

Mean mortality was $14.5 \pm 16.8,24.7 \pm 19.5$ and $11.0 \pm 12.1 \%$ at Ronce, Rivière d'Auray and Baie des Veys respectively. A significant difference in mortality was found among sites $\left(\chi^{2}=\right.$ $50.9, P<0.0001$ ) with a significantly higher mortality for oysters tested in Rivière d'Auray. Mortality for the $\mathrm{G} 2$ on October $8^{\text {th }} 2002$ is shown for each line in Table 3. Mean mortality across the sites was 6.1, 12.4, and $29.5 \%$, for the "high" selected line, control line and "low" selected line, respectively. A significant difference in mortality was found among these lines $\left(\chi^{2}\right.$ $=143.2, P<0.0001)$ as well as a significant interaction between lines and sites $\left(\chi^{2}=40.1, P<\right.$ $0.0001)$.

Within each site, significant differences in mortality were found among lines (Ronce: $\chi^{2}=102.6$, $P<0.0001$; Rivière d'Auray: $\chi^{2}=328.9, P<0.0001$; Baie des Veys: $\chi^{2}=13.7, P=0.0007$ ). Thus, the line selected for "low" survival had a significantly higher mortality than the other lines in each site. At Ronce and Baie des Veys, the control line and the "high" selected line showed similar mortality, while in Rivière d'Auray the line selected for "high" survival had a significantly lower mortality than the control (Table 3). At Rivière d'Auray, the control line showed intermediate survival that was significantly different from both selected lines. 
Taking a closer look at the data, all batches of the "low" selected line showed high mortality levels in Ronce (data not shown) and Rivière d'Auray (Fig. 2), ranging from 20 to $64 \%$, with the exception of batches $\mathrm{W}$ and $\mathrm{P}$ at Ronce (9\%). At Baie des Veys, where the mortality was low, batches $\mathrm{C}, \mathrm{J}$ and $\mathrm{M}$ of the "low" selected line showed mortality over $20 \%$ (data not shown). Conversely, mortality never exceeded $12 \%$ for all batches of the "high" selected line in any of the sites. Finally, controls had low mortality (1 to $13 \%)$ at all sites except Rivière d'Auray, where summer mortality ranged from 17 to $32 \%$ (Fig. 2).

Growth: At the point when the oysters were transferred to the field (July $11^{\text {th }} 2002$ ), initial mean weights were very similar between the lines $(1.1 \pm 0.2 \mathrm{~g}$ for the "high' selected line, $1.1 \pm 0.2$ for the "low" selected line and $1.0 \pm 0.1 \mathrm{~g}$ for the control line). At the end of the experiment, in October 2002, the mean weights of oysters at Ronce, Rivière d'Auray, and Baie des Veys were $7.7 \pm 3.1,8.7 \pm 3.0$, and $13.7 \pm 5.1 \mathrm{~g}$, respectively, representing a significant difference in growth among sites $(F=190.6, P<0.0001)$. Oysters reared at Baie des Veys showed the fastest growth, while growth was similar between those in Rivière d'Auray and Ronce. Mean weights for the G2 on October $8^{\text {th }} 2002$ are shown in Table 3: weights for the "high," "low" and control lines were 9.0, 8.9 and $9.1 \mathrm{~g}$, respectively. No significant differences in growth were found among lines $(F=0.85, P=0.44)$ and the site-by-line interaction was not significant $(F=$ 2.15, $P=0.10)$.

Yield: The daily yield of G2 oysters is presented in Table 3. Comparison among sites showed a significant difference $(F=194.5, P<0.0001)$, with the highest yield in Baie des Veys $(15.3 \pm 3.4$ $\left.\% . \mathrm{d}^{-1}\right)$, intermediate in Ronce $\left(7.1 \pm 2.1 \% . \mathrm{d}^{-1}\right)$ and the lowest in Rivière d'Auray $\left(6.1 \pm 2.1 \% . \mathrm{d}^{-}\right.$ $\left.{ }^{1}\right)$. A similar result was found among lines $(F=6.9, P=0.006)$ with the "low" selected line showing a significantly lower yield than the two other lines (Table 3 ). There was no significant site-by-line interaction for the daily yield $(F=2.1, P=0.08)$.

\subsection{Second generation - G2c: within-HSF parentage}

Mortality: Mean mortality of the G2c was $19.6 \pm 26.9 \%$ after the summer period, with a significant difference among lines $\left(\chi^{2}=31.13, P<0.0001\right)$. The line selected for "high" survival and the control both showed similar low mortality (<4\%), whereas mortality reached $43.4 \%$ for the oysters of the "low" selected line (Table 4). All batches of the "low" selected line showed high mortality levels, ranging from 18 to $82 \%$, with the exception of batches H2 (8 \%) and L2 (2 $\%)$. Conversely, mortality never exceeded $12 \%$ for batches of the "high" selected line after two months in the field. As in G2, the control had low mortality (<5\%).

Growth: Individual weights at deployment were $1.1 \pm 0.6 \mathrm{~g}$ for the "high" selected line, $1.4 \pm 0.8$ $\mathrm{g}$ for the "low" selected line and $0.9 \pm 0.5 \mathrm{~g}$ for the control line. In October 2002, individual weights ranged from 4.5 to $5 \mathrm{~g}$ (Table 4$)$. Growth was significantly different among lines $(F=$ $5.88, P=0.009$ ) with the best growth shown by the "high" selected line, intermediate for the control and the lowest for the "low" selected line.

Yield: Daily yield of the three lines ranged from $1.9 \% . \mathrm{d}^{-1}$ for the "low" selected line to $5.5 \% . \mathrm{d}^{-1}$ for the control (Table 4), corresponding to a significant difference among lines $(F=11.8, P=$ 0.0003).

\subsection{Third generation - G3: between-HSF parentage}

Mortality: Mean mortality of all batches produced in the G3 was $48.7 \pm 26.4 \%$ on October $8^{\text {th }}$. A significant difference in survival was observed among lines $\left(\chi^{2}=539.63, P<0.0001\right)$, with the lowest summer mortality in the line selected for "high" survival $(26.4 \%)$, intermediate in the control (47.3\%) and the highest mortality in the "low" selected line (71.1\%) (Table 4). Mortality recorded for each batch of the $\mathrm{G} 3$ in the Rivière d'Auray site is presented in Fig. 3. After three 
months in the field "low" selected batches showed high mortality levels, ranging from 50 to 92 $\%$, whereas mortality for "high" selected batches ranged from 11 to $51 \%$.

Growth: Individual weight at deployment was $2.1 \pm 1.2 \mathrm{~g}$ for the "high" selected line, $2.2 \pm 1.3 \mathrm{~g}$ for the "low" selected line and $2.3 \pm 1.6 \mathrm{~g}$ for the control line. On October $8^{\text {th }} 2003$, weight ranged from $13.0 \mathrm{~g}$ for the "high" selected line to $15.7 \mathrm{~g}$ for the control (Table 4), but no significant difference of growth was observed among lines $(F=0.63, P=0.54)$.

Yield: A significant difference in daily yield was found among lines $(F=23.64, P<0.0001)$. The highest daily yield was observed for the "high" selected line $\left(3.3 \% . \mathrm{d}^{-1}\right)$, the lowest for the "low" selected line $\left(0.8 \% . \mathrm{d}^{-1}\right)$, while control line had intermediate yield $\left(1.8 \% . \mathrm{d}^{-1}\right)$ (Table 4$)$.

\subsection{Third generation $-G 3 c^{2}$ : within-HSF parentage}

Mortality: Mean mortality on October $8^{\text {th }} 2003$ was $53.2 \pm 29.2 \%$. A significant difference in mortality was found among lines $\left(\chi^{2}=333.01, P<0.0001\right)$ with the lowest summer mortality for the "high" selected line, intermediate for the control and the highest for the "low" selected line (Table 4). Batches of the lines selected for "low" survival showed high mortality levels, ranging from 39 to $91 \%$, while mortality was lower and moderate for the batches of the "high" selected line, ranging from 6 to $52 \%$ except for batch VV2, in which only $8 \%$ of the spat put out in the field survived to the end of the experiment.

Growth: Individual weights at deployment were $2.0 \pm 1.1 \mathrm{~g}$ for the "high" selected line, $2.0 \pm 1.2$ $\mathrm{g}$ for the "low" selected line and $1.4 \pm 0.7 \mathrm{~g}$ for the control. In October, weights ranged from 8.3 $\mathrm{g}$ for the control to $10.2 \mathrm{~g}$ for the selected lines (Table 4), and there was no significant difference among lines $(F=0.34, P=0.72)$.

Yield: Daily yields ranged from 0.3 to $2.0 \% . \mathrm{d}^{-1}$ and, like in the $\mathrm{G} 2$, were significantly different among lines $(F=5.83, P=0.0097)$. The "low" selected line had the lowest yield, while the 'high" selected line had the highest (Table 4).

\subsection{Third generation - G3C}

Mortality: Mean mortality on October $8^{\text {th }} 2003$ was $44.6 \pm 19.2 \%$, with a significant difference of survival among lines $\left(\chi^{2}=292.41, P<0.0001\right)$. The "High" selected line and control showed similar mortality, around $25 \%$, and differed significantly from the "low" selected line which suffered a much higher mortality rate $(60 \%)$ (Table 4). The batches of the "low" selected line showed a high mortality level, ranging from 42 to $78 \%$, while mortality was lower for the "high" selected batches: ranging from 20 to $44 \%$.

Growth: Individual weights ranged from $1.5 \pm 0.7$ to $6.9 \pm 2.4 \mathrm{~g}$ for the "high" selected line, $1.6 \pm$ 0.8 to $7.1 \pm 2.5 \mathrm{~g}$ for the "low" selected line and $1.4 \pm 0.7$ to $8.3 \pm 2.5 \mathrm{~g}$ for the control. No significant difference of growth was observed among lines $(F=2.11, P=0.15)$.

Yield: Daily yields were significantly different among lines $(F=59.58, P<0.0001)$. The "high" selected line was found to have a yield three times that of the "low" selected line, but the control had the highest value (Table 4).

\subsection{Realized heritabilities}

Selection differentials, responses to selection and realized heritabilities estimated from the two selected lines for mortality are presented in Table 5. Significant responses to selection were observed for all five sets in all sites over the two years and generations considered. Realized heritability of survival for $\mathrm{G} 2$ was estimated at $0.70 \pm 0.09$ in Ronce, $0.61 \pm 0.08$ in Rivière d'Auray, and $0.95 \pm 0.23$ in Baie des Veys. From the data combined across all sites, the realized heritability of mortality was $0.64 \pm 0.07$. Similar data was obtained in the $\mathrm{G} 2 \mathrm{c}$ and the $\mathrm{G} 3$, with estimates of realized heritability ranging from $0.55 \pm 0.18$ in $\mathrm{G}^{2} \mathrm{c}^{2}$ to $0.98 \pm 0.15$ in G2c. 
All realized heritabilities were found to be significantly different from $0(P<0.0001)$ and correlations between mid-parent value and the performance of each progeny batch were high ranging from 0.40 to 0.91 .

In Rivière d'Auray, selection differential was higher for the "low" selected line than the "high" selected line for the $\mathrm{G} 2$ and the $\mathrm{G} 3$ (Table 6). Response to selection ranged from $17.1 \%$ to $20.4 \%$ in the upward direction for the "high" selected line and from 19.8 to $25.1 \%$ in the downward direction for the "low" selected line. Realized heritabilities for mortality in 6-month-old juveniles were high for the two selected lines, with higher value for the "high" selected line, ranging from $0.88 \pm 0.05$ to $1.02 \pm 0.20$, than the "low" selected line, ranging from $0.55 \pm 0.11$ to $0.68 \pm 0.10$.

\section{Discussion}

\subsection{Mortality}

Response to selection: Prior to the present study, realized heritability in shellfish had mostly been determined for growth-related traits, such as total weight, length or yield, and suggested that rapid genetic gains would be possible for these traits through selective breeding (Toro and Newkirk, 1990; Jarayabhand and Thavornyutikarn, 1995; Toro et al., 1995; Ibarra et al., 1999; Langdon et al., 2003; Zheng et al., 2004). Divergent selection for growth is relatively easy to perform because selection is based on animals that show the slowest or fastest growth. For survival, however, although selection can easily be made to increase survival, it is more difficult to perform in the downward direction, for the obvious reason that dead animals cannot be used as broodstock. Furthermore, the use of animals that have survived a massive mortality event could bias the response to selection through the "resistance" they have shown. Simply by retaining surviving individuals, one increasingly reduces the pressure of selection and consequently its efficiency as the process is continued (Chevassus and Dorson, 1990). The originality of our study was to maintain part of each family or batch produced in the Generation 1 and Generation 2 in conditions without mortality risks and to use these animals as the broodstock. This strategy allowed significant differences in resistance to mortality to develop between the two selected lines for all sets in all sites in Generation 2 and Generation 3. Indeed, lines selected for "high" survival showed much lower mortality than lines selected for "low" survival and the difference in mortality between the two lines indicates there is a significant genetic component that can be used in a selection program to improve the resistance of juvenile C. gigas against summer mortality pressures. Realized heritabilities estimated from the divergent selection on survival (or mortality) were high, ranging from $0.55 \pm 0.18$ to $0.98 \pm 0.15$. These high realized heritabilities obtained from the Generation 2 and Generation 3 confirmed the results obtained in the first generation where heritability estimates for survival ranged from 0.47 to 1.08 (Dégremont et al., 2007). Our results also agree with those reported for C. gigas on the US West Coast by Evans and Landgon (2006). The high heritability for survival indicates that selective breeding programs could effectively improve the survival of juvenile oysters, even though survival has previously been considered a difficult trait to improve through genetic selection (Gjedrem, 1985). We have shown that selection for survival in young $C$. gigas can result in survival over $90 \%$ at sites that otherwise had high summer mortality of hatcheryproduced spat placed in the field the same year. The maintenance of high additive genetic variance for survival in French oyster populations is discussed in Dégremont et al. (2007). Briefly, it could result from a lack of stabilizing selection combined with effects of the rearing cycle used for oyster aquaculture in France, trade-offs between survival and other fitness- 
related traits (Ernande et al., 2004) or life-history trait modification related to hatchery propagation (i.e. reproduction early in the year and intensive nursery rearing).

Although realized heritability estimates were high and constant among the five sets, some caution should be considered as the selection differential and the response to selection could varied among years, as the summer mortality in juvenile $C$. gigas depends of a complex interaction between the oyster, the environment and the pathogens (Samain et al., 2007). In "good years" (i.e. low summer mortality) selective pressure is weak and the resulting gain limited. Alternatively, in "bad years", only genetically superior families are likely to show limited mortality. In this context, more reliable estimates of the realized heritability to decrease or increase mortality should be obtained when parents and progenies are tested in a site and during a year in favour to the summer mortality phenomenon which was the case in Rivière d'Auray in 2002 and 2003. Conversely, more caution is needed for the realized heritability estimates obtained for the oysters tested in Baie des Veys, site where summer mortality is usually low in oysters $C$. gigas lesser than one year old, and for the oysters tested in Ronce. Indeed, it appears that a batch of oysters had a threshold beyond which mortality occurs. This threshold is different among batches and when it is reached, the mortality affects the oysters at an intensity which depends from the environment in which they are raised. In our study, the threshold of the G2 and G3 controls were reached in Rivière d'Auray and they experienced summer mortality (which was intermediate to the summer mortality of the two selected lines). However, the threshold of the G2 and G2c controls were not reached in Ronce, and they performed as good as the high selected line. As a consequence, estimation of realized heritability would be more reliable using the two selected lines than one selected line as differential selection allows the environmental effects common to all individuals of the two selected lines to be eliminated (Hill, 1972a). Finally, the low mortality of the G3c control and the high mortality of the $\mathrm{G}^{2} \mathrm{c}^{2}$ in Ronce in 2003 should be the result of the low number of parents (lesser than 10 parents per sex) combined to the high heritability of the trait. Indeed, the effective size could have been lower than expected due to differential survival at the larval and settlement stages (Boudry et al., 2002). As a consequence, it is really important to use a large number of parents to produce the controls and it seems essential to produce several of those in order to get the best estimate of response to selection to investigate the summer mortality phenomenon in juvenile oysters $C$. gigas.

Deployment and site effects: The low mortality level recorded two weeks after the G2 was deployed in the field confirmed that stress due to transportation and handling did not cause appreciable mortality at any of the three sites, as it did not in Generation 1 (Dégremont et al., 2005). Differences in mortality among sites for the $G 2$ in 2002 also show the same trends as those obtained for Generation 1 in 2001 (Dégremont et al., 2005). Spat produced in the hatchery during spring and deployed during the summer had the highest summer mortality at Rivière d'Auray ( $25 \%$ ), intermediate mortality at Ronce (14-16\%), and lowest mortality at Baie des Veys (from $6 \%$ in 2001 to $12 \%$ in 2002). Our results therefore support previous studies reporting higher mortality in estuarine environments compared with oceanic sites (Glude, 1975; Maurer et al., 1986, Soletchnik et al., 2007).

High mortality in 2003: High mortality rates recorded for the three sets of the G3 in 2003 could have been a result of a long and exceptional heat wave that year, with the highest minimum and maximum summer temperatures recorded in the last 50 years in France (Bessemoulin et al., 2004). Indeed, since C. gigas was introduced to France in the early 1970s, 2003 was the first time that these oysters experienced such unusual environmental conditions. The high mortality level recorded in juveniles in summer 2003 compared with normal levels recorded in adults 
suggests that young oysters are more fragile than adults during hot summers (Dégremont et al., 2003). Temperature has been demonstrated to play a major role in the induction of gametogenesis and dynamics of maturation, (Chávez-Villalba et al., 2002). Samain et al. (2007) showed our low selected line ("Susceptible" oysters) invested more energy in reproduction and stayed a longer time without spawning than high selected lines ("Resistant" oysters), which had high synchronous spawning. These relationships between temperature, reproduction and resistance to summer mortality might explain why mortality was higher in 2003.

Progenies from full-sib family F7-26: Generation 1 family F7-26 suffered mortality in the nursery before the crosses were made. In October 2002, all batches of the "low" selected line of G2 showed mortality $>20 \%$ at Ronce and Rivière d'Auray, except batches $\mathrm{W}$ and $\mathrm{P}$ at Ronce. These batches, like batches $A B$ and M, were the progeny of FSF F7-26 that had shown $25 \%$ mortality at the nursery stage in 2001. Mortality of FSF F7-26 could have reduced the "potential mortality" and/or the intensity of selection of the parental population by eliminating the weakest animals. Consequently, the selection differential was less effective and higher survival was observed for the four batches bred from FSF F7-26, compared with the other batches of the "low" selected line. Similar results were found in the G2c and G3c ${ }^{2}$, reinforcing this hypothesis. These results illustrate why, to make a better estimate of the realized heritability for survival with downward selection, it is essential to keep broodstock animals away from mortality risks.

\subsection{Growth}

Toro and Newkirk (1990) and Hand et al. (2004) found no effect for survival when selection was conducted for growth in the European flat oyster Ostrea edulis and Sydney rock oyster Saccostrea glomerata respectively. Conversely, Beattie (1985) reported slower growth for $C$. gigas selected for summer survival compared with control animals. Except for the G2c, our results show no significant differences in growth among lines (i.e. "high" and "low" selected lines and unselected control) of any sets (2002 or 2003) at any of the sites, indicating that selection for survival does not affect the summer growth performance of juvenile ( $<1$ year old) C. gigas. These results agree with the null or low negative genetic correlation previously found between growth and survival for oysters less than one year old (Dégremont et al., 2007).

\subsection{Yield}

Yield is determined by the combined effects of individual growth rate and survival (Blum, 1988). In the present study, yield was always higher for the lines selected for "high" survival compared with those selected for "low" survival (Tables 3 and 4). These results are the consequence of the selection on survival, as it was shown that high mortality is likely to decrease yield and that survival was the most important independent variable explaining yield in Ronce and Rivière d'Auray (Dégremont et al., 2005). Thus, selection to improve survival will automatically improve yield in juvenile $C$. gigas, and selective breeding programs to improve yield in this oyster should therefore firstly select individuals on the basis of survival and subsequently on growth.

\section{Conclusion}

A strong and positive response to selection for survival was observed in juvenile $C$. gigas at all sites. Generation 2 and Generation 3 results confirm those previously obtained from the first generation, showing a high heritability for survival in 1-year-old juvenile oysters. The present 
study represents the first demonstration of a genetic component for survival in a marine mollusk using divergent selection. Our results indicate that selective breeding programs could effectively improve summer survival in juvenile oysters. Selection for survival did not have a negative effect on growth performances of the progeny, while a significant positive effect was found for yield. Selection programs to improve yield in C. gigas should therefore select for survival prior to growth. The divergent "high" and "low" selection for survival described in this study produced live material that was "Resistant" and "Susceptible" to summer mortality, which was then studied as part of the multidisciplinary research project "Morest" for genetic, physiological and immunological characteristics (Samain et al., 2007; Huvet et al., 2008). New molecular applications, such as QTL (Quantitative Trait Loci) mapping (Sauvage, 2008), SSH (Suppressive Subtractive Hybridization) (Huvet et al., 2004), gene expression based on real time PCR, macro- and micro-arrays (Fleury et al., 2008) and pathogen detection (Pepin et al., 2008) have been developed by partners of the "Morest" project to further document differences between the selected progenies (Samain et al., 2007; Samain and McCombie, 2008). These studies contribute to further explaining the physiological basis of the genetic difference between these lines and the causative factors of summer mortality in $C$. gigas spat.

\section{Acknowledgements}

The authors wish to thank the hatchery (IFREMER-LGP, La Tremblade, France) and nursery (IFREMER-LCPL, Bouin, France) teams for technical assistance during the larval rearing and nursery stages, especially, P. Phélipot, S. Heurtebise and M. Nourry. This work could not have been completed without the participation of the many people who managed the oysters in the field and monitored their performances. We greatly thank the IFREMER coastal laboratory teams, particularly A. Langlade (Laboratoire Conchylicole de Bretagne, La Trinité sur Mer, France), P. Soletchnik and J.-L. Seugnet (Laboratoire Environnement Ressources des Pertuis Charentais, La Tremblade, France), Michel Ropert and Charlotte Simonne (Laboratoire Environnement Ressources de Normandie, Port en Bessin, France). Finally, we would like to thank the three anonymous reviewers, whose helpful comments on a previous version of the manuscript enabled us to substantially improve it, and Helen McCombie for her help with the English.

\section{References}

Baker, R. L., Morris, C. A., Johnson, D. L., Hunter, J. C., Hickey, S. M., 1991. Results of selection for yearling growth or 18 month weight in Angus and Hereford cattle. Livest. Prod. Sci. 29, 277-296.

Barber, B. J., Carnegie, R. B., Davis, C. V., 1996. Effect of timing of seed deployment on growth and mortality of oysters, Crassostrea virginica, affected by juvenile oyster disease (JOD). J. World Aquacult. Soc. 27, 443-448.

Barber, B. J., Davis, C.V., Crosby, M. A., 1998. Cultured oysters, Crassostrea virginica, genetically selected for fast growth in the Damariscotta River, Maine, are resistant to mortality caused by juvenile oyster disease (JOD). J. Shellfish Res. 17, 1171-1175.

Baud, J.-P., Gérard, A., Naciri-Graven, Y., 1997. Comparative growth of Bonamia ostreae resistant and wild flat oysters, Ostrea edulis, in an intensive upwelling system : I. First year of experiment. Mar. Biol. 130, 71-79. 
Beattie, J. H., 1985. Effects of growth and mortality differentials on production among selected stocks of the Pacific oyster Crassostrea gigas (Thunberg). J. Shellfish Res. 5, 49.

Beattie, J., Chew, K. Hershberger, W., 1980. Differential survival of selected strains of Pacific Oysters (Crassostrea gigas) during summer mortality. Proc. Nat. Shellfish. Ass. 70, 184-189.

Bessemoulin, P., Bourdette, N., Courtier, P., Manach, J., 2004. La canicule d'août 2003 en France et en Europe. La Météorologie, Volume 46, VIIle série.

Blum, A., 1988. Plant breeding for stress environments. CRC Press, Boca Raton, FL, USA.

Boettcher, K.J., Geaghan, K.K., Maloy, A.P., Barber, B.J. 2005. Roseovarius crassostreae sp. nov., a member of the Roseobacter clade and the apparent cause of juvenile oyster disease (JOD) in cultured Eastern oysters. Int. J Syst. Evol. Microbiol. 55, 1531-1537.

Boudry, P., Collet, B., Cornette, F., Hervouet, V., Bonhomme, F., 2002. High variance in reproductive success of the Pacific oyster (Crassostrea gigas, Thunberg) revealed by microsatellite-based parentage analysis of multifactorial crosses. Aquaculture 204, 283-296.

Burreson, E., 1991. Effects of Perkinsus marinus infection in the Eastern oyster, Crassostrea virginica: I. Susceptibility of native and MSX-resistant stocks. J. Shellfish Res. 10, 417-423.

Calvo, L.M., Calvo, G.W., Burreson, E., 2003. Dual resistance in a selectively bred eastern oyster, Crassostrea virginica, strain tested in Chesapeake Bay. Aquaculture 200, 69-87.

Chávez-Villalba, J., Pommier, J., Andriamiseza, J., Pouvreau, S., Barret, J., Cochard, J.-C., Le Pennec, M., 2002. Broodstock conditioning of the oyster Crassostrea gigas: origin and temperature effect. Aquaculture 214, 115-130.

Cheney, D.P., MacDonald, B. F., Elston, R. A., 2000. Summer mortality of Pacific oysters, Crassostrea gigas (Thunberg): Initial findings on multiple environmental stressors in Puget Sound, Washington, 1998. J. Shellfish Res. 19, 353-359.

Chevassus, B., Dorson, M., 1990. Genetics of resistance to disease in fishes. Aquaculture 85: 83-107.

Chintala, M. M., Fisher, W. S., 1991. Disease incidence and potential mechanisms of defense for MSX-resistant and -susceptible Eastern oysters held in Chesapeake Bay. J. Shellfish Res. 10, 439-443.

Culloty, S.C., Cronin, M.A., Mulcahy, M.F., 2004. Potential resistance of a number of populations of the oyster Ostrea edulis to the parasite Bonamia ostreae. Aquaculture 237, 4158.

Davis, C. V., Barber, B. J., 1994. Size-dependent mortality in hatchery-reared populations of oysters, Crassostrea virginica, Gmelin 1791, affected by juvenile oyster disease. J. Shellfish Res. 13, 137-142.

Davis, C.V., Barber, B. J., 1999. Growth and survival of selected lines of eastern oysters, Crassostrea virginica (Gmelin 179) affected by juvenile oyster disease. Aquaculture 178, 253271.

Dégremont, L., A. Fortin and P. Boudry, 2003. Caractérisation sur estran et en laboratoire des 3 séries produites en troisième génération: G3SD - G3C1 - G3C2. Rapport IFREMER, La Tremblade, France.

Dégremont, L., Bédier, E., Soletchnik, P., Ropert, M., Huvet, A., Moal, J., Samain, J-F., Boudry, P., 2005. Relative importance of family, site, and field placement timing on survival, growth and yield of hatchery-produced Pacific oyster spat (Crassostrea gigas). Aquaculture 249, 213-229.

Dégremont, L., Ernande, B., Bédier, E., Boudry, P., 2007. Summer mortality of hatcheryproduced Pacific oyster spat (Crassostrea gigas). I. Estimation of genetic parameters for survival and growth. Aquaculture 262, 41-53.

Deslous-Paoli, J. M., Héral, M., 1988. Biochemical composition and energy value of Crassostrea gigas (Thunberg) cultured in the bay of Marennes-Oléron. Aquat. Living Resour. 1, 239-249. 
Elston, R. A., Kent, M. L., Wilkinson, M. T., 1987. Resistance of Ostrea edulis to Bonamia ostreae infection. Aquaculture 64, 237-242.

Ernande, B., Boudry, P., Clobert, J., Haure, J., 2004. Plasticity in resource allocation based life history traits in the Pacific oyster, Crassostrea gigas. I. Spatial variation in fund abundance. J. Evol. Biol. 17, 342-356.

Evans, S., Langdon, C., 2006. Effects of genotype x environment interactions on the selection of broadly adapted Pacific oysters (Crassostrea gigas). Aquaculture 261, 522-534.

Falconer, D. S., 1981. Introduction to Quantitative Genetics. $2^{\text {nd }}$ edition, Longman, London.

Falconer, D. S., Mackay, T. F. C., 1996. Introduction to Quantitative Genetics. $4^{\text {th }}$ edition, Longman, Harlow, England.

Farley, C.A., Lewis, E.J., Relyea, D., Zahtila, J., Rivara, G., 1997. Juvenile oyster disease resistance studies: 1994-1996. J. Shellfish Res. 16, 331.

Farley, C.A., Lewis, E.J., Relyea, D., Zahtila, J., Rivara, G., 1998. Resistance studies for juvenile oyster disease (JOD) 1997: Some early insights into genetic aspects. J. Shellfish Res. 17, 352-353.

Fjalestad, K. T., Gjedrem, T., Gjerde, B., 1993. Genetic improvement of disease resistance in fish - An overview. Aquaculture 111, 65-74.

Fleury, E., Fabioux, C., Lelong, C., Favrel, P., Huvet, A., 2008. Characterization of a gonadspecific transforming growth factor-beta superfamily member differentially expressed during the reproductive cycle of the oyster Crassostrea gigas. Gene 410, 187-196.

Ford, S., Haskin, H.H., 1987. Infection and mortality patterns in strains of oysters Crassostrea virginica selected for resistance to the parasite Haplosporidium nelsoni (MSX). J. Parasitol. 73, 368-376.

Gjedrem, T. 1985. Improvement of productivity through breeding schemes. Geojournal 10, 233241.

Glude, J.B., 1975. A summary report of Pacific coast oyster mortality investigations 1965-1972. Proceedings of the Third U.S.-Japan Meeting on Aquaculture, Tokyo, Japan. October 15-16, 1974, pp. 1-28.

Goulletquer, P., Soletchnik, P., Le Moine, O., Razet, D., Geairon, P., Faury, N., Taillade, S., 1998. Summer mortality of the Pacific cupped oyster Crassostrea gigas in the Bay of MarennesOléron (France). Cons. int. Explor. Mer, CM 1998 / CC 14: 20 p.

Hand, R.E., Nell, J.A., Thompson, P.A., 2004. Studies on triploid oysters in Australia XIII. Performance of diploid and triploid Sydney rock oyster, Saccostrea glomerata (Gould, 1850), progeny from a third generation breeding line. Aquaculture 233, 93-107.

Haskin, H. H., Ford, S. E., 1979. Development of resistance to Minchinia nelsoni (MSX) mortality in laboratory-reared and native oyster stocks in Delaware Bay. Mar. Fish. 54-63

Haskin, H. H., Stauber, L. A., Mackin, J. A., 1966. Minchinia nelsoni n. sp. (Haplosporida, Haplosporidiidae): causative agent of the Delaware Bay oyster epizootic. Science 153, 14141416.

Hershberger, W. K., Perdue, J. A., Beattie, J. H., 1984. Genetic selection and systematic breeding in Pacific oyster culture. Aquaculture 39, 237-245.

Hill, W. G., 1971. Design and efficiency of selection experiments for estimating genetic parameters. Biometrics 27, 293-311.

Hill, W. G., 1972a. Estimation of realised heritabilities from selection experiments. I. Divergent selection. Biometrics 28, 747-765.

Hill, W. G., 1972b. Estimation of realised heritabilities from selection experiments. II. Selection in one direction. Biometrics 28, 767-780.

Hill, W. G., Thompson, R.,1977. Design of experiments to estimate offspring-parent regression using selected parents. Anim. Prod. 24, 163-168.

Hulata, G., 2001. Genetic manipulations in aquaculture: a review of stock improvement by classical and modern technologies. Genetica 111, 155-175. 
Huvet A., Herpin, A., Dégremont, L., Labreuche, Y., Samain, J.-F., Cunningham, C., 2004. The identification of genes from the oyster Crassostrea gigas that are differentially expressed as a result of summer mortality. Gene 343, 211-220.

Huvet, A., Royer, J., Burgeot, T., Lapègue, S., Boulo, V., Nicolas, J.L., Lambert, C.,Van Wormhoudt, A., Samain, J.F., 2008. Phenotypic characteristics of ' $R$ ' and ' $S$ ' oyster lines, selected for resitance or susceptibility to summer mortality. In: Samain, J.F., McCombie, H., (Eds.), Summer mortality of Pacific oyster Crassostrea gigas. Ed. Quae, pp 197-241.

Ibarra, A. M., Ramirez, J. L., Ruiz, C. A., Cruz, P., Avila, S., 1999. Realized heritabilities and genetic correlation after dual selection for total weight and shell width in catarina scallop (Argopecten ventricosus). Aquaculture 175, 227-241

Jarayabhand, P., Thavornyutikarn, M., 1995. Realized heritability estimation on growth rate of oyster, Saccostrea cucullata Born, 1778. Aquaculture 138, 111-118.

Koganezawa, A., 1975. Present status of studies on the mass mortality of cultured oysters in Japan and its prevention. Proceedings of the Third U.S.-Japan Meeting on Aquaculture, October 15-16, 1974, Tokyo, Japan, pp. 29-34.

Langdon, C., Evans, F., Jacobson, D., Blouin, M., 2003. Yields of cultured Pacific oysters Crassostrea gigas Thunberg improved after one generation of selection. Aquaculture 220, 227244.

Lipovsky, V., Chew, K., 1972. Mortality of Pacific oysters (Crassostrea gigas): the influence of temperature and enriched seawater on oyster survival. Proc. Nat. Shellfish Assoc. 62, 72-82.

Maurer, D., Comps, M., His, E., 1986. Caractéristiques des mortalités estivales de l'huître Crassostrea gigas dans le bassin d'Arcachon. Haliotis 15, 309-317.

Naciri-Graven, Y., Martin, A. G., Baud, J.-P., Renault, T., Gérard, A., 1998. Selecting the flat oyster Ostrea edulis (L.) for survival when infected with the parasite Bonamia ostreae. J. Exp. Mar. Biol. Ecol. 224, 91-107.

Needler, A. W. H., Logie, R.R., 1947. Serious mortalities in Prince Edward Island oysters caused by a contagious disease. Trans. R. Soc. Canada, XLI III, 73-89.

Newkirk, G. F., 1980. Review of the genetic and the potential for selective breeding of commercially important bivalves. Aquaculture 19, 209-228.

Parnell, P. F., Arthur, P. F., Barlow, V., 1997. Direct response to divergent selection for yearling growth rate in Angus cattle. Livest. Prod. Sci. 49, 297-304.

Pepin, J.F., Riou, A., Renault, T., 2008. Rapid and sensitive detection of ostreid herpesvirus 1 in oyster samples by real-time PCR. J. Virol. Methods 149, 269-276.

Robertson, A., 1959. Experimental design in the evaluation of genetic parameters. Biometrics 15, 219-226.

Samain, J.F., Dégremont, L., Soletchnik, P., Haure, J., Bédier, E., Ropert, M., Moal, J., Huvet, A., Bacca, H., Van Wormhoudt, A., Delaporte, M., Costil, K., Pouvreau, S., Lambert, C., Soudant, P., Nicolas, J.L., Le Roux., F., Renault, T., Gagnaire, B., Géret, F., Boutet, I., Burgeot, T., Boudry, P., 2007. Genetically based resistance to summer mortality in the Pacific oyster (Crassostrea gigas) and its relationship with immunological characteristics and infection processes. Aquaculture 268, 227-243.

Samain, J.F., McCombie, H., 2008. Summer mortality of Pacific oyster Crassostrea gigas. Ed. Quae, 379p.

SAS Institute Inc., 1989. SAS/STAT ${ }^{\circledR}$ User's Guide. Version 6, Fourth Edition, Volume 2. SAS Institute Inc., Cary, NC.

SAS Institute Inc., 1995. Basis statistics using SAS/STAT ${ }^{\circledR}$, Software Course Notes. SAS Institute Inc., Cary, NC.

Sauvage C., 2008. Développement de marqueurs moléculaires liés à la résistance à la mortalité estivale chez l'huître creuse Crassostrea gigas - approche QTL. PhD thesis, Univeristy of La Rochelle, France, 271 p. 
Sheridan, A. K., 1997. Genetic improvement of oyster production - a critique. Aquaculture 153, 165-179.

Soletchnik, P., Huvet, A., Le Moine, O., Razet, D., Geairon, P., Faury, N., Goulletquer, P., Boudry, P., 2002. Comparative field study of growth, survival and reproduction of Crassostrea gigas, C. angulata and their hybrids. Aquat. Living Res. 15(4), 243-250.

Soletchnik, P., Ropert, M. Mazurié, J., Fleury, P.G., Le Coz, F., 2007. Relationships between oyster mortality patterns and environmental data from monitoring databases along the coasts of France. Aquaculture 271, 384-400.

Taris, N., Ernande, B., McCombie, H., Boudry, P., 2006. Phenotypic and genetic consequences of size selection at the larval stage in the Pacific oyster (Crassostrea gigas). J. Exp. Mar. Biol. Ecol. 333, 147-158.

Toro, J. E., Newkirk, G.F., 1990. Divergent selection for growth rate in the European oyster Ostrea edulis: response to selection and estimation of genetic parameters. Mar. Ecol. Prog. Ser. 62, 219-227.

Toro, M., Sanhueza, M. A, Winter, J.E., Aguila, P., Vergara, M., 1995. Selection response and heritability estimates for growth in the Chilean oyster Ostrea chilensis (Philippi, 1845). J. Shellfish Res. 14, 87-92.

Zheng, H.P., Zhang, G.F., Liu, X., Zhang, F.S., Guo, X.M., 2004. Different responses to selection in two stocks of the bay scallop, Argopecten irradians irradians Lamarck (1819). J. Exp. Mar. Biol. Ecol. 313, 213-223.

\section{Figures}

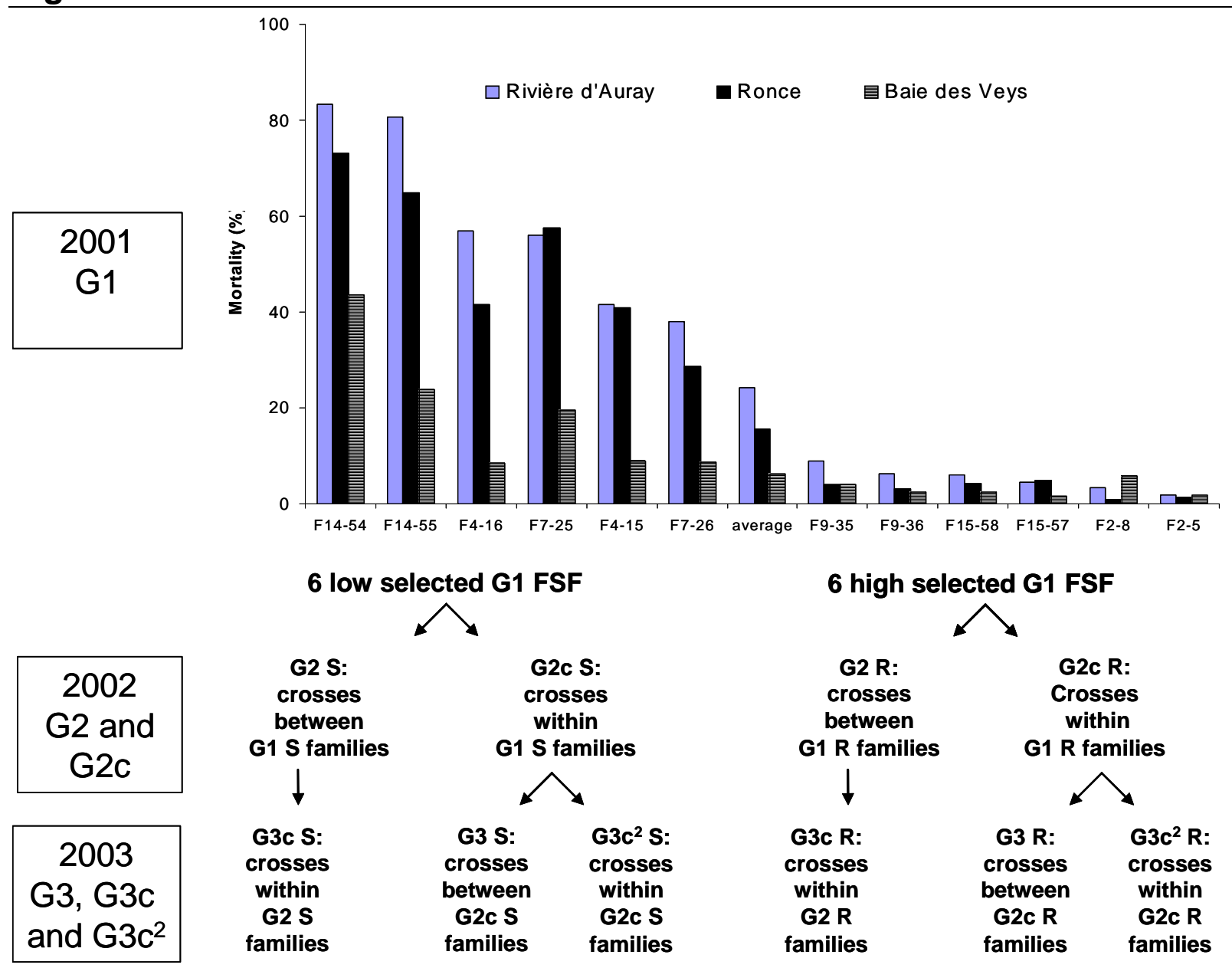


Fig. 1. Summary of the production of the Generations 2 and 3 made from the full-sib families (FSF) selected in Generation 1 according to their mortality performances in Ronce, Rivière d'Auray and Baie des Veys.

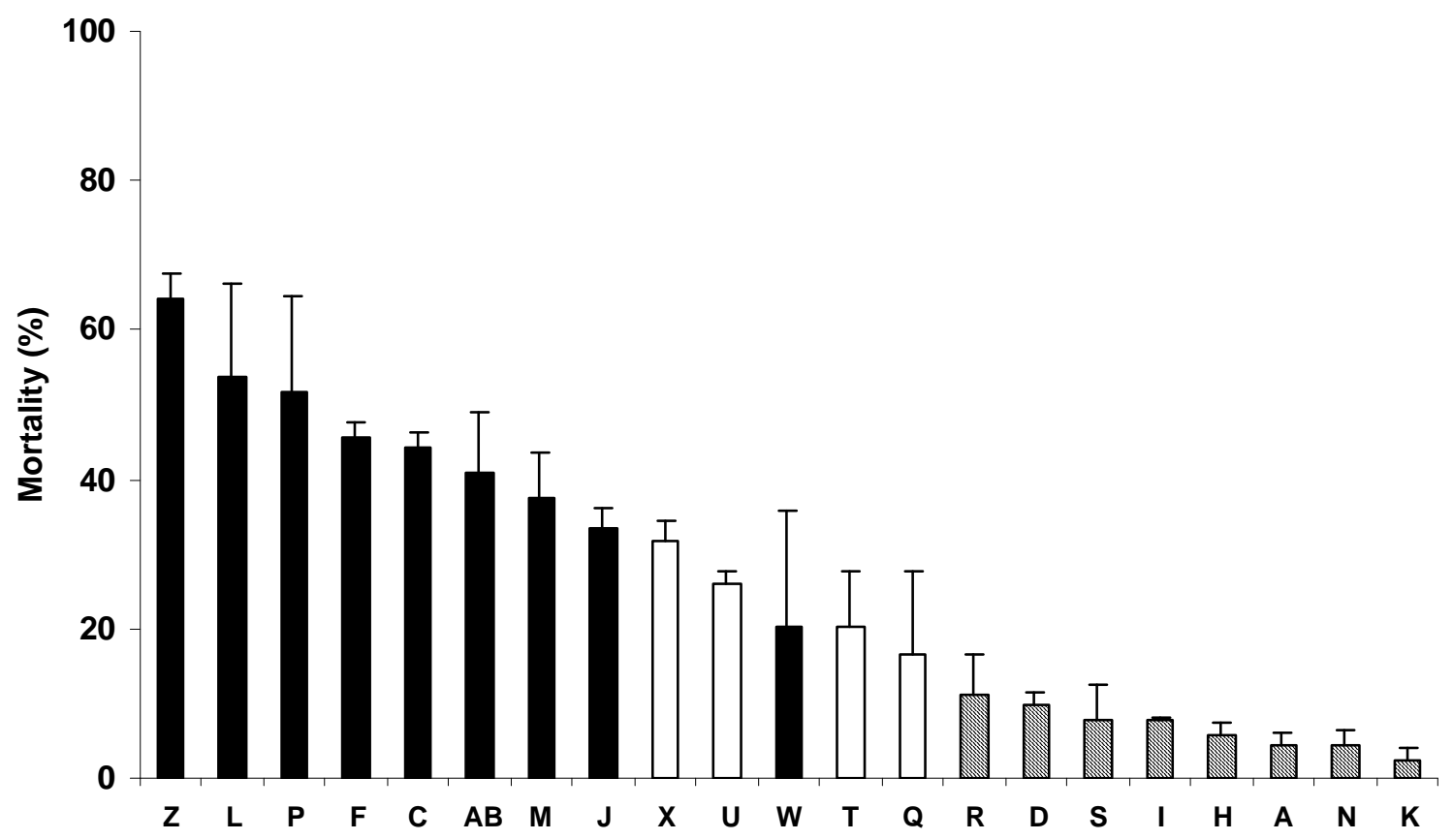

Fig. 2. Mortality $(\%+S D)$ of each $G 2$ batch in Rivière d'Auray on October $8^{\text {th }} 2002$; solid bars $=$ batches selected for low survival, shaded bars = batches selected for "high" survival, open bar = control batch. 


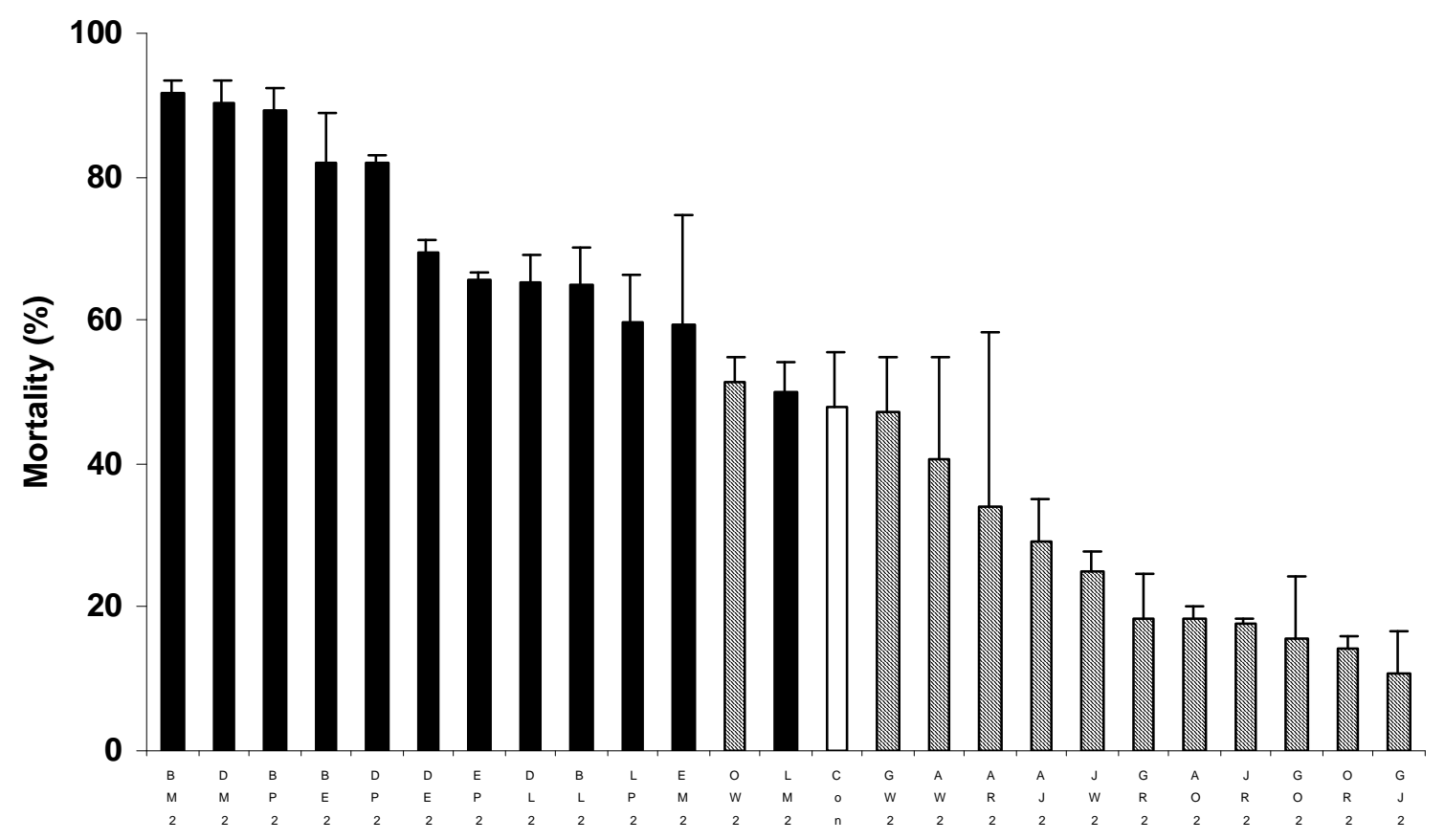

Fig. 3. Mortality $(\%+S D)$ of each G3 batch in Rivière d'Auray on October $8^{\text {th }} 2003$; solid bars = batches selected for low survival, shaded bars = batches selected for "high" survival, open bar = control batch. 
Table 1. Mating design used to produce $G 2$ and G2c sets of $C$. gigas produced in the second generation in 2002 (See section 2.1 of the text for detail of the experimental design).

\begin{tabular}{|c|c|c|c|c|c|c|c|c|}
\hline \multirow{2}{*}{ Selected line } & \multirow[t]{2}{*}{ HSF } & \multicolumn{3}{|c|}{2} & \multicolumn{2}{|l|}{9} & \multicolumn{2}{|l|}{15} \\
\hline & & FSF & $F 2-5$ & F2-8 & F9-35 & F9-36 & F15-57 & F15-58 \\
\hline \multirow{8}{*}{ "high" } & \multirow{2}{*}{2} & F2-5 & A2 & $\mathrm{C} 2$ & A & D & I & K \\
\hline & & F2-8 & F2 & G2 & $E$ & $\mathrm{H}$ & $\dagger$ & $\mathrm{N}$ \\
\hline & \multirow{2}{*}{9} & F9-35 & & & $\mathrm{J} 2$ & K2 & O & $\mathrm{R}$ \\
\hline & & F9-36 & & & N2 & $\mathrm{O} 2$ & S & V \\
\hline & \multirow{2}{*}{15} & F15-57 & & & & & R2 & S2 \\
\hline & & F15-58 & & & & & V2 & W2 \\
\hline & \multirow[t]{2}{*}{ HSF } & & 4 & & 7 & & 14 & \\
\hline & & FSF & F4-15 & F4-16 & F7-25 & F7-26 & F14-54 & F14-55 \\
\hline \multirow{6}{*}{ "low" } & \multirow{2}{*}{4} & F4-15 & $\dagger$ & Y2 & $\dagger$ & W & B & C \\
\hline & & F4-16 & B2 & D2 & Z & $A B$ & $\mathrm{~F}$ & G \\
\hline & \multirow{2}{*}{7} & F7-25 & & & E2 & $\mathrm{H} 2$ & $\mathrm{~J}$ & L \\
\hline & & F7-26 & & & 12 & L2 & M & P \\
\hline & \multirow{2}{*}{14} & F14-54 & & & & & M2 & P2 \\
\hline & & F14-55 & & & & & Q2 & $\dagger$ \\
\hline
\end{tabular}

The shaded area indicates $\mathrm{G} 2$ batches and white area G2c batches;

$\dagger$ indicates that larval rearing failed and the batch was lost at this stage;

HSF: half-sib family;

FSF: full-sib family. 
Table 2. Batches of $C$. gigas produced in 2003 for the three sets of crosses making up the third generation $\mathrm{G} 3$.

\begin{tabular}{|c|c|c|c|c|c|}
\hline \multicolumn{2}{|l|}{$\mathrm{G}^{\mathrm{a}}$} & \multicolumn{2}{|l|}{$G 3 c^{2 b}$} & \multicolumn{2}{|l|}{$G 3 c^{c}$} \\
\hline "high" & "low" & "high" & "low" & "high" & "low" \\
\hline selected & selected & selected & selected & selected & selected \\
\hline line & line & line & line & line & line \\
\hline AJ2 & BE2 & AA2 & YY2 & AA & WW \\
\hline $\mathrm{AO} 2$ & BL2 & CC2 & BB2 & DD & ZZ \\
\hline GJ2 & DE2 & FF2 & DD2 & EE & ABAB \\
\hline GO2 & DL2 & GG2 & YB2 & $\mathrm{HH}$ & BB \\
\hline AR2 & BM2 & JJ2 & EE2 & II & CC \\
\hline GR2 & BP2 & KK2 & $\mathrm{HH} 2$ & $\mathrm{KK}$ & $\mathrm{FF}$ \\
\hline AW2 & DM2 & NN2 & II2 & NN & GG \\
\hline GW2 & DP2 & OO2 & LL2 & OO & $\mathrm{JJ}$ \\
\hline JR2 & EM2 & RR2 & MM2 & RR & LL \\
\hline JW2 & EP2 & SS2 & PP2 & SS & MM \\
\hline OR2 & LM2 & VV2 & QQ2 & V & PP \\
\hline OW2 & LP2 & WW2 & PQ2 & & \\
\hline
\end{tabular}

a G3 was produced using G2c oysters as parents (see Table 1). For example, AJ2 was produced with pooled reciprocal crosses between batches A2 and J2: A2 females were crossed with $\mathrm{J} 2$ males and $\mathrm{J} 2$ females with A2 males.

b $\mathrm{G}^{2} \mathrm{c}^{2}$ was produced using G2c oysters as parents (see Table 1). For example, AA2 was produced using crosses between A2 males and A2 females. Reciprocal crosses were used to obtain batches YB2 and PQ2.

${ }^{\mathrm{C}} \mathrm{G} 3 \mathrm{c}$ was produced using G2 oysters as parents (see Table 1). For example, AA was produced using crosses between A males and A females. 
Table 3. Means and standard deviations of mortality, individual weight and daily yield in 6month-old juvenile oysters $C$. gigas of set G2, reared at the three sites from July $11^{\text {th }} 2002$ to October $8^{\text {th }} 2002$ and assessed at final sampling.

\begin{tabular}{|c|c|c|c|c|}
\hline & & "high" & "low" & \\
\hline & Site & selected line & selected line & control line \\
\hline Mortality (\%) & Ronce & $5.3 \pm 5.0^{a}$ & $34.1 \pm 21.1^{b}$ & $7.9 \pm 9.7^{a}$ \\
\hline & Rivière d'Auray & $6.6 \pm 3.7^{a}$ & $43.4 \pm 14.5^{c}$ & $23.7 \pm 8.3^{b}$ \\
\hline & Baie des Veys & $7.4 \pm 3.8^{\mathrm{a}}$ & $17.3 \pm 16.9^{b}$ & $5.5 \pm 2.4^{\mathrm{a}}$ \\
\hline & Total & $6.1 \pm 4.0^{\mathrm{a}}$ & $29.5 \pm 19.7^{c}$ & $12.4 \pm 11.0^{b}$ \\
\hline Individual weight (g) & Ronce & $8.0 \pm 3.2^{\mathrm{a}}$ & $7.4 \pm 3.1^{\mathrm{a}}$ & $7.5 \pm 2.9^{a}$ \\
\hline & Rivière d'Auray & $9.2 \pm 3.2^{\mathrm{a}}$ & $8.2 \pm 2.6^{a}$ & $8.9 \pm 3.2^{a}$ \\
\hline & Baie des Veys & $12.9 \pm 4.6^{\mathrm{a}}$ & $14.0 \pm 5.5^{\mathrm{a}}$ & $14.9 \pm 5.2^{\mathrm{a}}$ \\
\hline & Total & $9.0 \pm 4.0^{\mathrm{a}}$ & $8.9 \pm 4.4^{a}$ & $9.1 \pm 4.5^{\mathrm{a}}$ \\
\hline Daily yield $\left(\% . d^{-1}\right)$ & Ronce & $7.8 \pm 1.3^{\mathrm{a}}$ & $5.4 \pm 2.2^{b}$ & $7.4 \pm 2.0^{\mathrm{a}}$ \\
\hline & Rivière d'Auray & $7.8 \pm 1.0^{\mathrm{a}}$ & $4.4 \pm 1.8^{c}$ & $6.2 \pm 1.3^{b}$ \\
\hline & Baie des Veys & $15.1 \pm 2.1^{a}$ & $14.2 \pm 4.3^{a}$ & $17.6 \pm 1.9^{a}$ \\
\hline & Total & $10.4 \pm 3.7^{\mathrm{a}}$ & $8.2 \pm 5.2^{b}$ & $10.4 \pm 5.5^{a}$ \\
\hline
\end{tabular}

Means with different superscripts differ significantly among lines $(P<0.05)$. 
Table 4. Means and standard deviations of mortality, individual weight and daily yield 6-monthold juvenile oysters $C$. gigas for set G2c and for the three sets produced in third generation (G3, $\mathrm{G} 3 \mathrm{c}^{2}$ and $\mathrm{G} 3 \mathrm{c}$ ) assessed at the final sampling.

\begin{tabular}{|c|c|c|c|c|c|}
\hline Generation & Site & Parameter & $\begin{array}{l}\text { "high" } \\
\text { selected line }\end{array}$ & $\begin{array}{l}\text { "low" } \\
\text { selected line }\end{array}$ & control line \\
\hline \multirow[t]{3}{*}{ G2c ${ }^{A}$} & Ronce & Mortality (\%) & $3.5 \pm 4.4^{\mathrm{a}}$ & $43.4 \pm 33.8^{b}$ & $3.7 \pm 3.6^{a}$ \\
\hline & & Individual weight $^{\mathrm{E}}(\mathrm{g})$ & $5.0 \pm 2.1^{a}$ & $4.9 \pm 2.2^{c}$ & $4.5 \pm 2.0^{b}$ \\
\hline & & Daily yield $\left(\% . d^{-1}\right)$ & $4.2 \pm 0.6^{b}$ & $1.9 \pm 2.3^{\mathrm{c}}$ & $5.5 \pm 0.7^{a}$ \\
\hline \multirow[t]{3}{*}{$\mathrm{G} 3^{\mathrm{B}}$} & Rivière d'Auray & Mortality (\%) & $26.4 \pm 14.8^{\mathrm{a}}$ & $71.1 \pm 14.8^{c}$ & $47.3 \pm 8.2^{b}$ \\
\hline & & Individual weight $^{\mathrm{E}}(\mathrm{g})$ & $13.0 \pm 5.4^{\mathrm{a}}$ & $14.9 \pm 5.7^{a}$ & $15.7 \pm 8.0^{\mathrm{a}}$ \\
\hline & & Daily yield $\left(\% . d^{-1}\right)$ & $3.3 \pm 0.9^{a}$ & $0.8 \pm 1.0^{c}$ & $1.8 \pm 0.7^{b}$ \\
\hline \multirow[t]{3}{*}{$\mathrm{G} 3 \mathrm{c}^{2 \mathrm{C}}$} & Ronce & Mortality (\%) & $34.6 \pm 25.9^{a}$ & $73.1 \pm 18.5^{c}$ & $61.6 \pm 16.0^{b}$ \\
\hline & & Individual weight $^{\mathrm{E}}(\mathrm{g})$ & $10.0 \pm 4.1^{\mathrm{a}}$ & $10.2 \pm 4.5^{\mathrm{a}}$ & $8.3 \pm 3.1^{a}$ \\
\hline & & Daily yield $\left(\% . d^{-1}\right)$ & $2.0 \pm 1.3^{a}$ & $0.3 \pm 1.1^{\mathrm{c}}$ & $1.1 \pm 0.9^{b}$ \\
\hline \multirow[t]{3}{*}{$\mathrm{G} \mathrm{c}^{\mathrm{D}}$} & Ronce & Mortality (\%) & $29.6 \pm 7.7^{a}$ & $60.4 \pm 10.7^{b}$ & $24.0 \pm 5.2^{a}$ \\
\hline & & Individual weight $^{\mathrm{E}}(\mathrm{g})$ & $6.9 \pm 2.4^{\mathrm{a}}$ & $7.1 \pm 2.5^{\mathrm{a}}$ & $8.3 \pm 2.5^{a}$ \\
\hline & & Daily yield $\left(\% . d^{-1}\right)$ & $3.0 \pm 0.6^{b}$ & $1.0 \pm 0.7^{c}$ & $4.5 \pm 1.1^{\mathrm{a}}$ \\
\hline
\end{tabular}

${ }^{A}$ G2C was produced on April $28^{\text {th }} 2002$, deployed on August $8^{\text {th }} 2002$ and final sampling was on October $8^{\text {th }} 2002$.

${ }^{B}$ G3 was produced on February $17^{\text {th }} 2003$, deployed on July $1^{\text {st }} 2003$ and final sampling was on October $8^{\text {th }} 2003$.

${ }^{C} \mathrm{G} 3 \mathrm{c}^{2}$ was produced on March $24^{\text {th }} 2003$, deployed on July $16^{\text {th }} 2003$ and final sampling was on October $8^{\text {th }} 2003$.

${ }^{\mathrm{D}} \mathrm{G} 3 \mathrm{C}$ was produced on April $28^{\text {th }} 2002$, deployed on July $31^{\text {st }} 2003$ and final sampling was on October $8^{\text {th }} 2003$.

E Difference among lines is given for growth rather than individual weight.

Means with different superscripts differ significantly among lines $(P<0.05)$.

Table 5: Selection differentials (S), responses to selection (R) and realized heritabilities $\left(h^{2} r\right) \pm$ SE for survival in 6-month-old juvenile oysters $C$. gigas and correlation ( $r$ ) between mid-parent value and the performance of each progeny batch.

\begin{tabular}{llllll}
\hline Set & Site & S (\%) & R (\%) & $h^{2} r$ & $r$
\end{tabular}




\begin{tabular}{llllll}
\hline G2 & Ronce & 48.2 & 28.7 & $0.70 \pm 0.09$ & 0.82 \\
& Rivière d'Auray & 55.2 & 36.8 & $0.61 \pm 0.08$ & 0.89 \\
& Baie des Veys & 15.2 & 9.9 & $0.95 \pm 0.23$ & 0.60 \\
& All sites & 38.3 & 23.4 & $0.64 \pm 0.07$ & 0.91 \\
& Ronce & 47.7 & 39.6 & $0.98 \pm 0.15$ & 0.71 \\
G2C & Rivière d'Auray & 55.8 & 45.5 & $0.76 \pm 0.10$ & 0.85 \\
G3 & Ronce & 48.4 & 38.5 & $0.55 \pm 0.18$ & 0.47 \\
G3c & & 48.2 & 30.8 & $0.81 \pm 0.13$ & 0.40 \\
G3c & Ronce & & & & \\
\hline
\end{tabular}

Table 6: Selection differentials (S), responses to selection $(R)$ and realized heritabilities $\left(h^{2} r\right) \pm$ SE to decrease ("high" selected line) or increase ("low" selected line) mortality in 6-month-old juvenile oysters $C$. gigas in Rivière d'Auray, and correlation ( $r$ ) between mid-parent value and the performance of each progeny batch.

\begin{tabular}{lcccc}
\hline Set & $\mathrm{S}(\%)$ & $\mathrm{R}(\%)$ & $\mathrm{h}^{2} \mathrm{r}$ & $\mathrm{r}$ \\
\hline G2 "high" selected line & -19.4 & -17.1 & $0.88 \pm 0.05$ & 0.40 \\
G2 "low" selected line & 35.8 & 19.8 & $0.55 \pm 0.11$ & 0.27 \\
G3 "high" selected line & -19.1 & -20.4 & $1.02 \pm 0.20$ & 0.20 \\
G3 "low" selected line & 36.1 & 25.1 & $0.68 \pm 0.10$ & 0.27 \\
\hline
\end{tabular}

